\title{
Assessment of Climate Trends and Land Cover/Use Dynamics within the Somone River Basin, Senegal
}

\author{
Ndeye Yacine Barry ${ }^{1,2 *}$, Vieux Boukhaly Traore ${ }^{3,4}$, Mamadou Lamine Ndiaye ${ }^{4}$, \\ Osemwegie Isimemen1, Hauhouot Celestin'1, Bienvenu Sambou² \\ ${ }^{1}$ West African Science Service Center on Climate Change and Adapted Land Use (WASCAL), Felix Houphouet-Boigny \\ University, Abidjan, Côte d'Ivoire \\ ${ }^{2}$ Institut des Sciences de l'Environnement, Faculté des Sciences et Techniques, Université Cheikh Anta Diop de Dakar, \\ Dakar, Sénégal \\ ${ }^{3}$ Laboratoire d'Hydraulique et Mécanique des Fluides, Université Cheikh Anta Diop de Dakar, Dakar, Sénégal \\ ${ }^{4}$ Laboratoire d'Enseignement et de Recherche en Géomatique, Campus universitaire de l'Ecole Supérieure \\ Polytechnique de Dakar, Dakar, Sénégal \\ Email: *yacemine87@yahoo.fr
}

How to cite this paper: Barry, N.Y., Traore, V.B., Ndiaye, M.L., Isimemen, O., Celestin, H. and Sambou, B. (2017) Assessment of Climate Trends and Land Cover/Use Dynamics within the Somone River Basin, Senegal. American Journal of Climate Change, 6, 513-538.

https://doi.org/10.4236/ajcc.2017.63026

Received: June 20, 2017

Accepted: August 26, 2017

Published: August 29, 2017

Copyright () 2017 by authors and Scientific Research Publishing Inc. This work is licensed under the Creative Commons Attribution International License (CC BY 4.0).

http://creativecommons.org/licenses/by/4.0/

\begin{abstract}
This study was undertaken mainly to 1 ) investigate temporal trends in annual rainfall and temperature; 2) identify discontinuities in the time series; and 3) assess the Land Use/Land Cover Change (LULC) in the Somone coastal lagoon, within the river basin. The study examined temporal trends in rainfall (1931-2016) and temperature (1961-2016) datasets of Somone river basin, and breaks in time series using Mann-Kendall non-parametric test and other suitable statistical tools. Temporal evolution in LULC was assessed for the years 1954, 1978, 2003 and 2016. Analysis indicates a significant decreasing trend in precipitation over the basin. These trends are much more pronounced for minimum and average rainfall than for maximum and annual amplitudes. Contrary to precipitation, surface air temperature shows a significant increasing trend for its minimum and averages, and a decreasing trend for its maximum and amplitudes. A significant break in precipitation was observed in 1958, while surface air temperature presents much longer breaks within the years 1975 and 1977, and 1991 and 1993. A more direct implication of climate change on LULC patterns is increased in unproductive salt pans (Sabkhas). Increase in Sabkhas gave rise to conversion of forest lands to agricultural lands of local farmers in search for fertile soils to cater for the food needs of a growing population. Otherwise, the development of the settlements, favored by the tourism activity and agriculture crisis, is another cause of croplands decreasing. The findings of the present research clearly indicate that the impacts of climate change are exacerbated by rapid urbanization in the basin.
\end{abstract}




\section{Keywords}

Temperature, Rainfall, Climatic Change, Water Resources, LULC Patterns, Somone Coastal Lagoon

\section{Introduction}

Climate changes intricate relationship with the hydrologic cycle [1], and hence, exerts strong influence on water availability, as well as its quantity and quality [1] [2], especially in wetlands [3] [4]. Sea level rise and other consequences of global warming, such as increased storm flooding, inundation, coastal erosion and extreme heat events are expected to have negative consequences on global wetlands such as estuaries and coastal lagoons, through alteration of their hydrologic regime [3] [5]. Inundation of these low lying coastal areas may render them unfavorable to dependent flora and fauna, inclusive of migratory birds that rely on such habitats for resting and feeding during their winter migration [6]. In most developing countries, rainfall is the main source of recharge to wetlands, making them highly vulnerable to climate change [7]. Future climate change will also exacerbate already existing challenges such as population growth, changes in economic activity, land use, urbanization, agricultural water needs, household consumption and hydroelectric production [8] [9].

Recently, instability in the monsoons, evidenced by intense precipitation and abnormally long dry spells, in West Africa, particularly in the Sahel, has been attributed to climate change [10]. Droughts were recorded in Sahelian countries, among the 1970-1980 decades. However, rainfall averages were close to normal values since 1999 [11]. Results from the Global Circulation Models (GCMs) show that rainfall remains largely uncertain for the West African region. However, drying-out process is expected to affect West African countries up to $15^{\circ} \mathrm{N}$ latitude [11]. Rainfall projections for the Sahel coastlines are decreased frequency in rainfall events and intense storms surges with consequent higher surface runoffs [12] and Sudan regions have changed somewhat faster than the global trend. Since the late $1970 \mathrm{~s}$, temperature has been increasing at rates between $0.2^{\circ} \mathrm{C}$ to $0.8^{\circ} \mathrm{C}$, and since the end of the 1970s per decade [13], temperature has been projected to further increase by between $3.0^{\circ} \mathrm{C}$ and $4.0^{\circ} \mathrm{C}$ [11].

Regional changes in climate; in addition to alter the frequency and magnitude of extreme weather events [14] [15], will also affect species, distribution, diversity and productivity.

Global climate change has negatively impacted the whole biodiversity [16]. The main components of coastal systems will suffer because of future climate change. This is related with a rise in sea water temperature and a reduction in the light reaching the bottom, through the cumulative interaction of the rise in sea-level and increased water column turbidity [17]. Rising temperatures and the rainfall variability have also exacerbated the problem of wetlands disappearing 
[18].

Rainfall pattern shows spatiotemporal variations in distribution and the amount [14]. This variation in rainfall amount has been recognized as the most important parameter to characterize climate [19]. However, characterization of regional climate of an area is more robust when rainfall is combined with other parameters such as river flows, lake levels, groundwater levels and especially temperatures [20]. Assessing temporal trends, which is deviations from mean and variance [21] of these different meteorological parameters is therefore imperative to understand changes in local climate and subsequently, make future projections [22] [23] [24].

The changes in climate are highly exacerbated by human pressures, mainly in coastal areas, within the high urbanization, the industrialization, the over-exploitation of natural resources. This context, accentuates the LULC changes, with the natural area, replacement by building, road and other infrastructures, hence the decrease of the forest area and croplands. Consequently, the climate change can be pronounced [25]. Indeed, the degradation of the vegetation cover increases the ecosystem vulnerability contributing significantly to global change [26]. Land-cover change modifies surface albedo and thus surface-atmosphere energy exchanges, which have an impact on regional climate. Indeed, a decrease in plant cover may be accompanied by an increase in surface albedo [27].

Because of its location in the littoral, Somone coastal is exposed to urban development, including changes in LULC. These changes, added to the changing climate constituted huge threats to Somone coastal lagoon and associated ecosystems. Therefore, this study presents several scientific interests. First, it is useful to note that few climatic and land use studies based on serious linked analysis and methods have been conducted in the area. Secondly, the few studies done, were rather geographical order. Only Sakho analyzed with a simple description of the LULC Change system through land survey and often by GIS. This seems necessary but not sufficient to have a clear idea of how the system changed, within the changing climate, exacerbated by the human pressures. However, in this study, recognizing that good adaptation and mitigation policy implementation requires all the knowledges about climate risks and human pressures through the land cover/cover use. In fact, it is necessary to analyze climate patterns and LULC dynamic, to demonstrate how both influence each other. The work offers an opportunity to provide useful information for many Scientifics researchers and policymakers to understand the coastal lagoon behavior in face to natural and human pressures. This study can be considered then as a managing tool for policymakers and referential study for researchers about human and climate pressures analysis on a coastal lagoon in Sahelian country.

\section{Materials and Methods}

\subsection{Study Area}

Somone river basin (Figure 1) covers an area of $420 \mathrm{~km}^{2}$. It is geographically lo- 




Figure 1. Location of the study area.

cated between latitude $14^{\circ} 23^{\prime} 27^{\prime \prime} \mathrm{N}$ and longitude $16^{\circ} 57^{\prime} 17^{\prime \prime} \mathrm{W}$ [28], $77 \mathrm{~km}$ south of Dakar. It is bounded to the west by the Atlantic Ocean, to the north by the cliffs of Thiès, to the east and south by Nguékhokh plain. It encompasses Somone lagoon which is part of the RNICS (Somone Natural Reserve of Communal Interest) of about $7 \mathrm{~km}^{2}$ (700 ha), established in 1999, also constitutes part of this river basin. With a surface of $2.04 \mathrm{~km}^{2}$ Somone lagoon, located between latitudes $14^{\circ} 30^{\prime}$ and $14^{\circ} 50^{\prime} \mathrm{N}$ and longitude $17^{\circ} 10^{\prime} \mathrm{W}$ is the largest body of water within the basin. The RNICS encompasses three rural settlements: Guereo, Thiafoura and Sorokhassap (Sindia) and commune of Somone, in the region of Thies. Until its creation in 2008, Somone was part of Sindia. Its vegetation is mainly mangrove, which dominates the lagoon area. The climate is tropical Sahelo-Sudanian, characterized by two contrasting annual seasons: a long, dry, extremely hot season from November to May and a warm and short humid rainy season from June to October. Total annual rainfall is estimated at $760 \mathrm{~mm}$ at the Mbour station. Maximum monthly precipitation of $400 \mathrm{~mm}$ is recorded in August. The monthly average temperature is $27.31^{\circ}$. The highest temperature of $36.5^{\circ}$ was recorded in April and lowest temperature of $15^{\circ}$ is recorded either in December, 
January or February. The dry season is marked by the predominance of the trade wind, with a high relative humidity of $60 \%$. The rainy season is dominated by the south-west monsoon that flows from the St. Helena high. Air humidity is high with a maximum of $96 \%$ in August and September [29].

\subsection{Meteorological Data Analysis}

Although, there are two meteorological stations: Mbour and Nguekhokh Stations in the river basin, only the data (precipitation and temperature) from the Mbour station were considered in this study after a critical check on quality. Annual Rainfall Average and Monthly temperature average data at the Mbour meteorological station, over the period 1931-2016 and 1961-2016 were obtained from the National Agency for Civil Aviation and Meteorology (ANACIM). Minima, maxima and amplitude values for each climate variables were computed in MS Excel. Thereafter, time series data were plotted to observe trends in data distribution and, possibly, irregularities [30]. The non-parametric Mann-Kendall test was employed to test the significance of observed [31]. Mann-Kendall test is simple, robust and can cope with missing values, seasonality and values below detection limit [32] [33].

It is based on the calculation of reduced statistic of the test given by the Equation (1) [34]:

$$
U(S)=\frac{S-E(S)}{\sqrt{V(S)}}
$$

where $S$ and $E(S)$ are respectively the sum of the numbers and expected value of the mean. $V(S)$ is a variance given by Equation (2)

$$
V(S)=\frac{n(n-1)(2 n+5)}{72}
$$

The null hypothesis is rejected at the threshold of $\alpha=5 \%$, if $|U(S)|$ exceeds the critical value $U(S)_{1-\frac{\alpha}{2}}=1.96$ that is acquired from the standard normal cumulative distribution table [35]. If this is the case, there is an increasing trend for $U(S)>0$ and a decreasing trend for $U(S)<0$ in the data series [36]. This trend is significant if the $P$-value $<\alpha$.

\subsubsection{Detection of Breaks}

The existence of breaks, sudden changes in the time series data is a possible cause of the heterogeneity of the series [37]. Breaks are pivotal years of climate change [38]. Although, there exist numerous methods to detect discontinuities in time series datasets [39], segmentation procedure of Buishand and Hubert [40] was adopted in this study.

$$
\overline{X_{k}}=\frac{\sum_{i_{k-1}+1}^{i_{k}} X_{i}}{i_{k}-i_{k-1}}
$$


$D_{m}$ is the quadratic deviation between the series and the segmentation given by equation.

$$
D_{m}=\sum_{k=1}^{m} \sum_{i_{k-1}+1}^{i_{k}}\left(X_{i}-\bar{X}_{k}\right)^{2}
$$

For a given segmentation order, the algorithm determine the optimal segmentation of a series that is such that the deviation $D_{m}$ is minimal. According to [41], this procedure can also be interpreted as a stationary test, the null hypothesis being the studied series is non-stationary. If the procedure doesn't produce acceptable segmentations of order bigger or equal to two, the null hypothesis is accepted.

The null hypothesis $\left(\mathrm{H}_{0}\right)$ states that there is no shift in the time series, and is rejected at a significance level of $5 \%$. Time series are subdivided into $\mathrm{m}$ segments such that $m$ is greater than 1 and that the mean of two contiguous segments must be significantly different and satisfy the assumptions of Scheffe's test [42]. The procedure gives the timing of the breaks. Giving an $m^{\text {th }}$ order segmentation of the time series, $i_{k} k=1, m$, the rank in the initial series of extreme end of the $k^{\text {th }}$ segment (with $i_{0}=0$ ). The rupture tests were carried out using the Khronosta software (Institute for Research for Development (IRD).

\subsubsection{Hubert Procedure}

The Buishand test is applied under the assumption that the studied series is normally distributed. Then, the Buishand statistic is defined by Equation (5) [43].

$$
U=\frac{\sum_{k=1}^{N-1}\left(S_{k} / \sigma_{x}\right)^{2}}{N(N+1)}
$$

where the terms $S_{k}$ are the partial sum and $\sigma_{x}$ the standard deviation of the given series $\left(X_{i}\right)$ that tests for homogeneity can be based and given by Equation (6); $\bar{X}$ is the average of series [7].

$$
\sigma_{x}^{2}=\frac{1}{N} \sum_{i=1}^{N}\left(X_{i}-\bar{X}\right)^{2}
$$

The null hypothesis of the statistical test is the absence of shift in the series. In the rejection case of this hypothesis, the estimation of the shift date is made possible by the construction of a control ellipse. Under the null hypothesis assumption, the $S_{k}$ variable defined above, follows a normal distribution with a zero mean and a variance given by Equation (7) [43]

$$
\sigma^{2}=\frac{1}{N} k(N-k) \text {, With, } k=0 \text { to } N
$$

This control ellipse was used here to estimate visually the importance of the deviations under the null hypothesis of the homogeneity of the series. It is consequently possible to define confidence limits including the series of the $S_{k}$ [44].

Statistical significance of the magnitude of detected breaks was tested using 
the parametric student's t-test is a comparison of the means of two sub-series obtained on either side of the point of rupture [45]; This test makes it possible to say whether the ruptures linked to the variations of the climate possibly determined are significant or not. The statistic used in this test is:

$\checkmark$ for the numbers of sub-series $n_{1}$ and / or $n_{2}<30$ (at least one is small)

$$
T=\frac{\overline{X_{1}}-\overline{X_{2}}}{\sqrt{\left(\sigma^{2}\left(\frac{1}{n_{1}}+\frac{1}{n_{2}}\right)\right)}}
$$

where $\overline{X_{1}}$ and $\overline{X_{2}}$ are the averages of the respective two sample sizes $n_{1}$ and $n_{2}$ and $\sigma^{2}$ denotes the weighted common variance of the two samples given by Equation (9) [46].

$$
\sigma^{2}=\frac{\sum_{i=1}^{n_{1}}\left(X_{1, i}-\overline{X_{1}}\right)^{2}+\sum_{i=1}^{n_{2}}\left(X_{2, i}-\overline{X_{2}}\right)^{2}}{n_{1}+n_{2}-2}
$$

The statistic $T$ obtained, is compared with the reference value, read on the Student table, as a function of the number of degrees of freedom $v$, such that $L=n_{1}+n_{2}-2$ at the confidence threshold $\alpha$. If the absolute value of $T$ is greater than 1.96 or 2.53 , the mean difference is said to be significant at the threshold of $\alpha=5 \%$ or very significant at the threshold of $\alpha=1 \%$

$\checkmark$ for the numbers of sub-series $n_{1}$ and $n_{2}>30$ (all larger)

The test is then based on the reduced deviation given by Equation (10) [46].

$$
Z=\frac{\overline{X_{1}}-\overline{X_{2}}}{\sqrt{\left(\left(\frac{\sigma_{1}^{2}}{n_{1}}+\frac{\sigma_{2}^{2}}{n_{2}}\right)\right)}}
$$

$\sigma_{1}^{2}$ and $\sigma_{2}^{2}$ denote the variances estimated on each sample given respectively by Equations (11) and (12).

$$
\begin{gathered}
\sigma_{1}^{2}=\frac{\sum_{i=1}^{n_{1}}\left(X_{1, i}-\overline{X_{1}}\right)^{2}}{n_{1}} \\
\sigma_{2}^{2}=\frac{\sum_{i=1}^{n_{2}}\left(X_{2, i}-\overline{X_{2}}\right)^{2}}{n_{2}}
\end{gathered}
$$

If the absolute value of $Z$ is less than 1.96, the difference is said to be insignificant at the $5 \%$ threshold; if not, it is. Results are presented in tabular and graphical form.

\subsection{Spatial Data Analyses}

LULC patterns are used to understand the link between the dynamics of LULC change and climate variability, and the implication of each other to the natural area degradation, in Somone coastal lagoon and its surrounding. In this study, LULC patterns were carried from aerial photographs and satellite images cover- 
ing an area of $44 \mathrm{~km}^{2}$. The aerial photograph data were acquired from 1954 and 1978 by USGS and satellite images were generated from Quick Bird 2003 and GeoEye 2016. The choice of these images is initially linked to their availability, also to their high spatial resolution (less than $5 \mathrm{~m}$ for all images) and temporal (more than 50 years). These images and photographers were used to assess spatial and temporal dynamic of LULC. Image was geometrically registered into a Universal Transverse Mercator (UTM) projection, WGS 1984 and Zone 28 N. A minimum of seventeen (17) regularly distributed ground control points were selected from the images. Resampling was performed using a nearest neighbor algorithm. The transformation had an RMS error less than 1 pixel indicating that the image was accurate to within one pixel. For image classifications, the visual interpretation approach was selected, to extract LULC contents in remotely sensed data. Image classifications were done by visual interpretation, assisted by computer, to extract LULC contents in remotely sensed data. This approach avoids spectral confusion as well as isolated pixels. The interpretation of satellite imagery and aerial photographs involves the study of various basic characters of an object with reference to spectral bands which is useful in visual analysis. The basic elements are shape, size, pattern, tone, texture, shadows, location, association and resolution [47]. Advances in computer, GIS and remote sensing technology offer new possibilities for managing, editing and generating raster and vector data, facilitating the visual interpretation methods [48]. Visual interpretation assisted by computer was carried out with ArcGIS software 9.2 version (ESRI, US). Globally, eleven classes were identified in this study, including bare soil, Sabkha, beach, crop lands, forest area, lagoon, mangrove, settlements, Somone's river, tidal areas, and vegetated Sabkha. To achieve wide acceptance among users of thematic information generated using remote sensing data, the interpreter must be able to specify the accuracy of this product [49]. In this study, the accuracy assessment of thematic maps was carried out. The accuracy assessment is the procedure used to compare the classification results to the geographical reference data that are assumed to be right [50]. In fact, due to the lack of appropriate data available in the study area, the accuracy assessment for classification image ancients (i.e. 1954, 1978 and 2003) was not possible. Therefore, an accurate assessment was performed for the 2016 image only. For the 2016 image, a total of thirty-hundred-thirty (330) ground truth data (30 points from each class) were selected randomly in the study area by GPS, during a field mission of May 2017. The comparison of these reference points with classification results allowed realizing confusion matrices and thus calculating global precision and Kappa index.

\section{Results}

\subsection{Relating to Trend}

\subsubsection{By Graphical Approach}

- Temporal Changes in Rainfall Time Series 
We present in Table 1 the distribution of the different rainfall data considered according to their tendencies. Figures 2(a)-(d) represent the corresponding graphic trends. The table shows that all slopes are negative, implying a downward trend. The values of the $P$-values is given by the linear regression method give the magnitude of the trends at the threshold of $\alpha=5 \%$. The overall view of the figures and analysis of $P$-values suggest that these trends are much clearer for the mean and the minimal rainfall than for the maximum rainfall and amplitude.

\section{- Temporal Trends in Temperature}

We present in Table 2 the distribution of the different temperature data studied according to their tendencies. The Figures 3(a)-(d) represent the corres-

Table 1. Rainfall trend repartition.

\begin{tabular}{ccccc}
\hline & Slope Value & Trend Direction & $\boldsymbol{P}$-value & Trend Extent \\
\hline Pmin & -0.17 & Decrease & 0.0024 & Significant \\
Pmax & -1.25 & Decrease & 0.0254 & Significant \\
Pmean & -0.28 & Decrease & 0.0018 & Significant \\
Pamp & -1.08 & Decrease & 0.0508 & No Significant \\
\hline
\end{tabular}



(a)

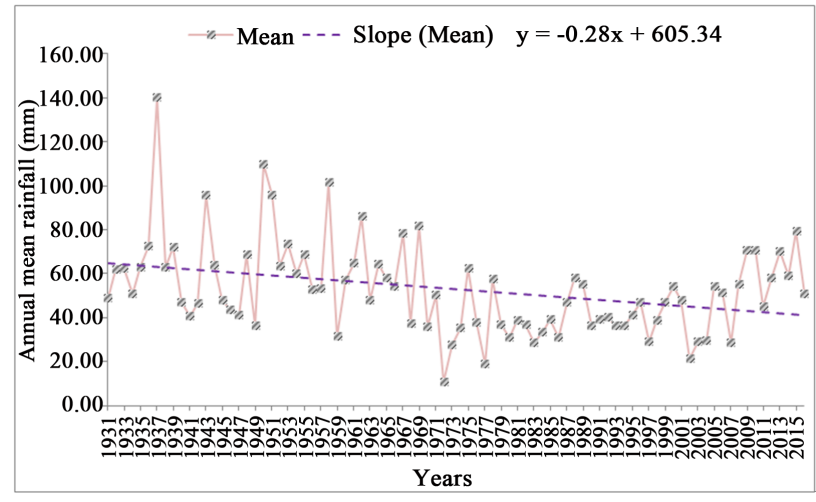

(c)

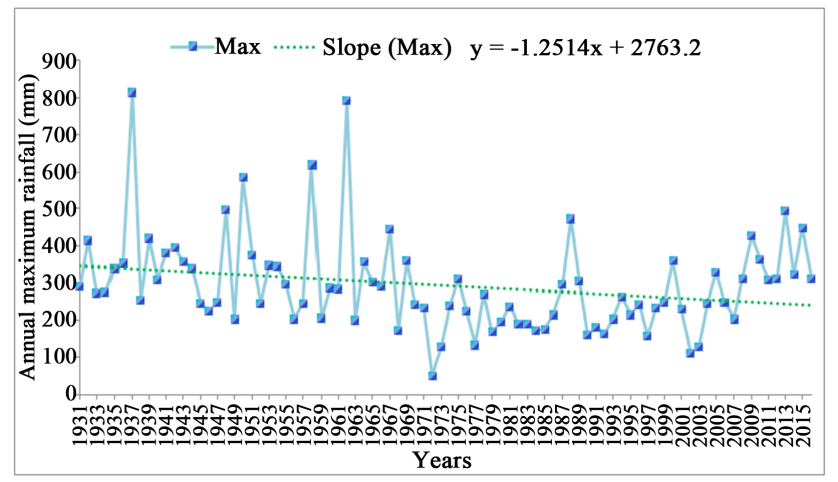

(b)

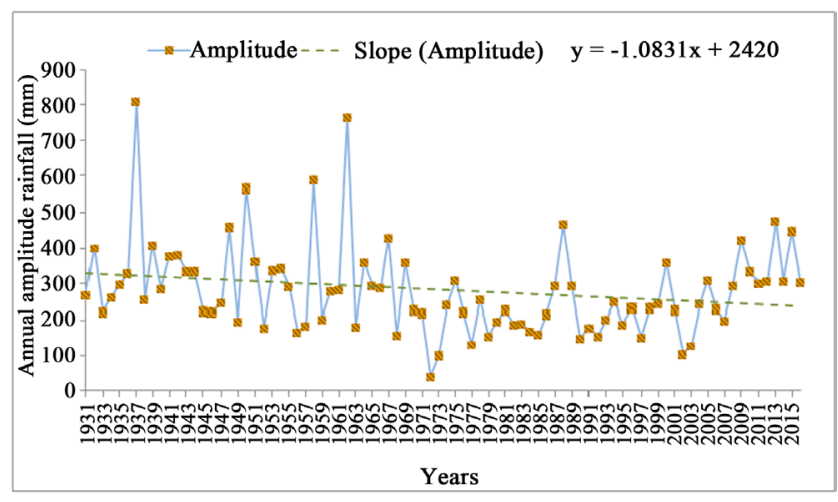

(d)

Figure 2. (a) Trend of annual minimum rainfall; (b) Trends of annual maximum rainfall; (c) Trend of Annual Mean Rainfall; (d) Trends of annual rainfall amplitude. 


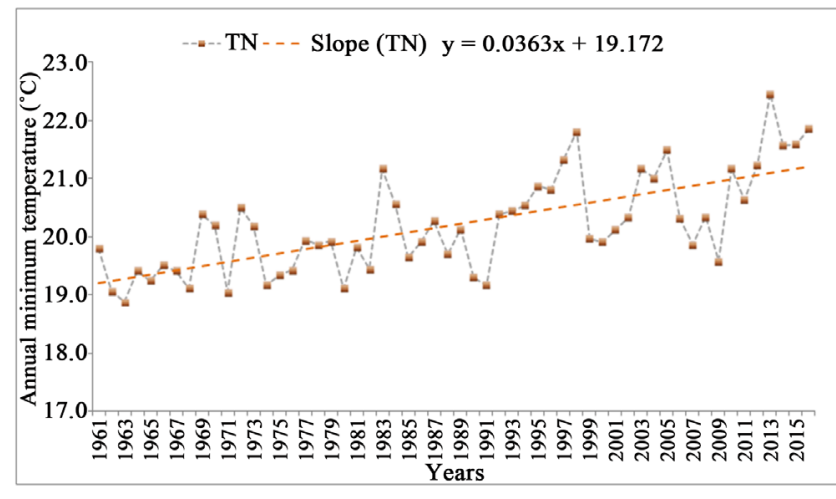

(a)

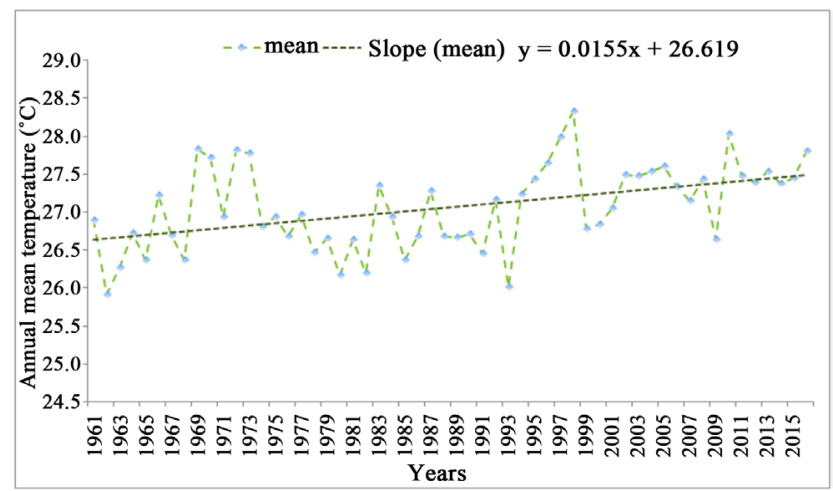

(c)



(b)

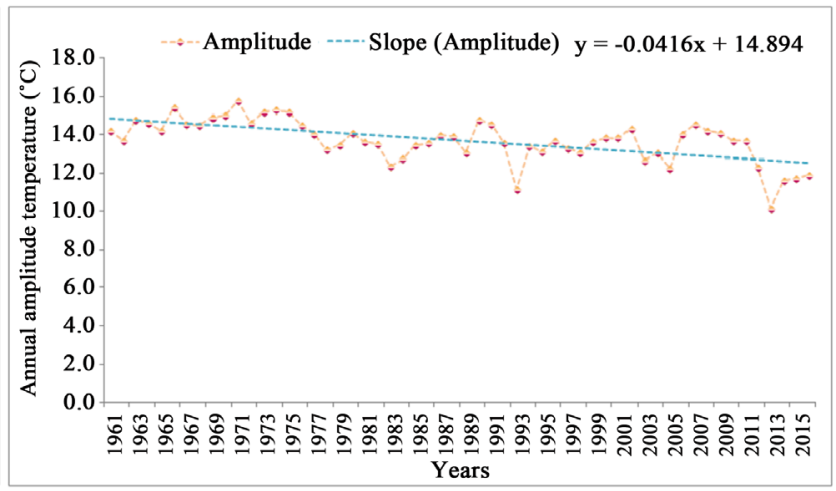

(d)

Figure 3. (a) Trends in Annual Minimum Temperatures; (b) Trends in Annual maximal temperature; (c) Trends in Annual mean temperatures; (d) Trends in annual amplitude temperatures.

Table 2. Distribution of temperature trends.

\begin{tabular}{ccccc}
\hline & Slope Value & Trend Direction & $P$-value & Trend Extent \\
\hline Tmin & 0.033 & Increase & $1.783 \times 10^{-9}$ & Significant \\
Tmax & -0.007 & Decrease & 0.37598 & No Significant \\
Tmean & 0.013 & Increase & 0.00047 & Significant \\
Tamp & 0.040 & Decrease & $5.365 \times 10^{-7}$ & Significant \\
\hline
\end{tabular}

ponding graphic trends. The table shows that the slopes are negative for amplitudes and maximum and positive to minimum and mean. This implies a decreasing and increasing trend, respectively. The $P$-values, by the linear regression method, give the magnitude of the trends at the threshold of $\alpha=5 \%$. The overall view of the figures and analysis of $P$-values suggest that the upward trend is much sharper for minimum temperatures than for mean temperatures and that the downward trend is much more pronounced for amplitudes than for maximum temperatures.

\subsubsection{By Mann-Kendall Test}

\section{- Rainfall Time Series}

We present in the Table 3 the results of Mann Kendall's trend tests. The ana- 
Table 3. Results of the Mann-Kandall test.

\begin{tabular}{ccccccc}
\hline & $\mathrm{U}(\mathrm{s})$ & $P$-value & Null Hypothesis & Trend Direction & Trend Extent & Classifying \\
\hline Pmin & -2.762 & 0.006 & Rejected & Decrease & Significant & 1 \\
Pmax & -2.134 & 0.033 & Rejected & Decrease & Significant & 3 \\
Pmoy & -2.656 & 0.008 & Rejected & Decrease & Significant & 2 \\
Pampl & -1.978 & 0.115 & Rejected & Decrease & Not significant & 4 \\
\hline
\end{tabular}

lysis of the table shows that the null hypothesis of an absence of trend in the series is rejected at the level of significance of $5 \%$ for all four categories of rainfall considered. In addition, all values of the Mann-Kendall $U(s)$ statistic are negative, implying a decreasing trend. Moreover, the use of $P$-values $\left(P_{V}<\alpha\right)$ watches except for the amplitudes, this trend is significant for the three types of rainfall data. Thus, $P$-values allow the rainfall data classification, according to the trends as indicated in the table.

\section{- Temperature Time Series}

Table 4 presents the results of Mann Kendall's trend tests. The null hypothesis of an absence of trend in the series is rejected at the 5\% significance level for all four temperature categories considered. In addition, the values of the MannKendall $U(s)$ statistics are negative for maximum temperatures and for amplitudes and are positive for minimum temperatures and mean temperatures. This implies that the trend is decreasing for maximum and amplitude temperatures and increasing for minimum temperatures and mean temperatures. Moreover, the use of $P$-values $\left(P_{V}<\alpha\right)$ hatches for maximum and average temperatures, this trend is not statistically significant, whereas for maximum temperatures and amplitudes, it is. Thus, the $P$-values allow classifying the temperature data studied according to the trends as indicated in the table.

\subsection{Relating to Shifts Detection Test}

\section{- Rainfall Time Series}

Table 5 presents the results of the rupture tests. Figures 4(a)-7(a) and Figures 4(b)-7(b) relate respectively to the Hubert and Buishand tests of the four- rainfall data considered. The table shows both the tests of Hubert and Buishand reject the null hypothesis of a lack of breaks at the level of significance of 5\%. The rupture date is given by the Buishand ellipse (Figures $4(\mathrm{~b})-7(\mathrm{~b})$ ) and corresponds to the year 1958 for minimum, 1967 for maximum and amplitude and 1969 for a mean. The Hubert test (Figures 4(a)-7(a)) corroborates this result, proposing again the same date for the four categories of rainfall data considered. This break gives a general downward trend for the four categories of rainfall data considered. The agreement of these results makes it possible to conclude that the chronological series is not homogeneous and can therefore be divided into two subseries as: 1931-1958 and 1959-2016 for minimum; 1931-1967 and 1968-2016 for maximum and amplitude; 1931-1969 and 1970-2016 for mean. 


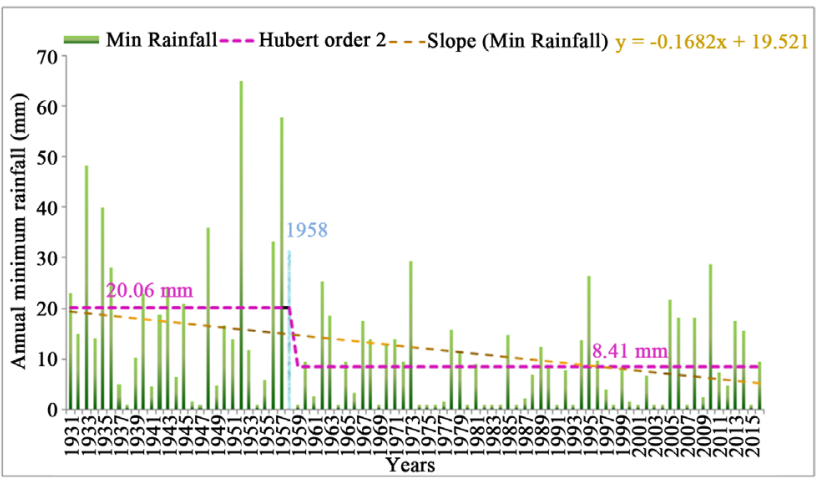

(a)

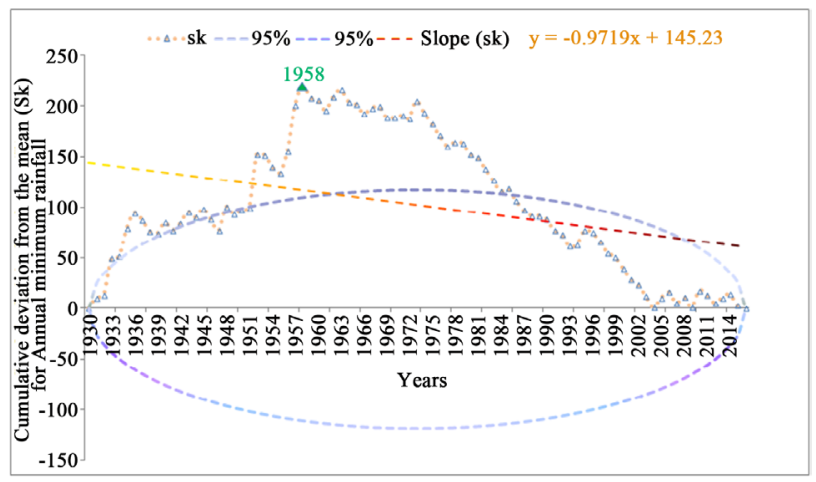

(b)

Figure 4. (a) Hubert diagram at order 2 for annual minimum; (b) Buishand control ellipse for annual minimum.

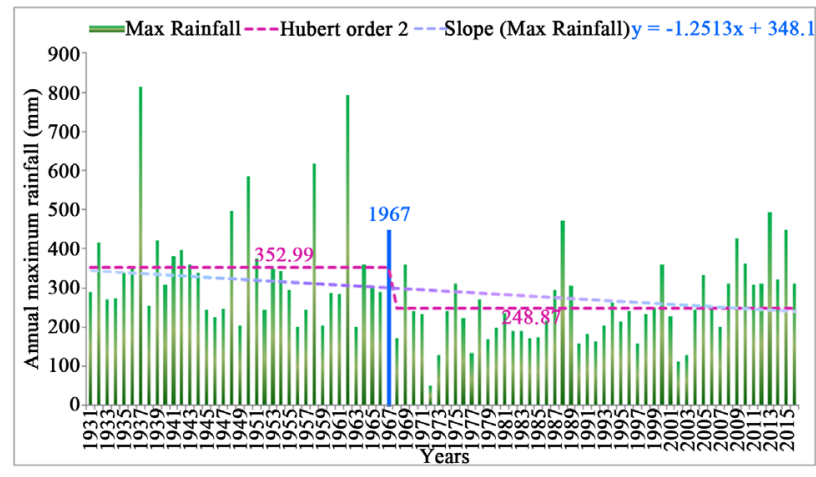

(a)

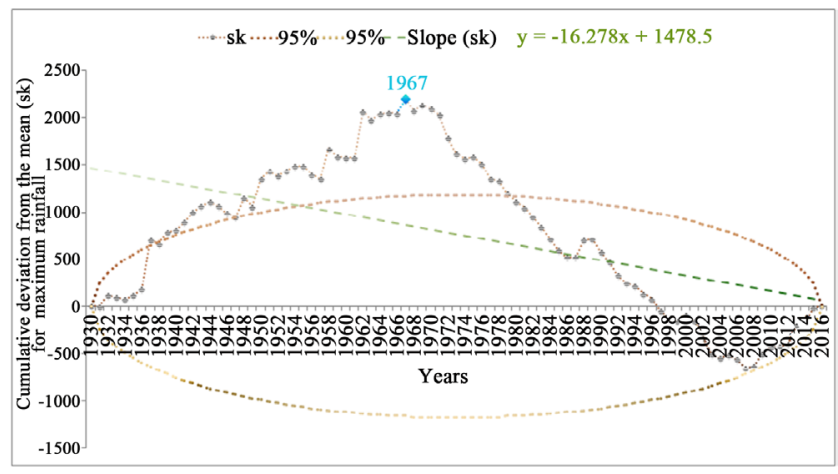

(b)

Figure 5. (a) Hubert diagram at order 2 for annual maximum; (b) Buishand control ellipse for annual maximum.

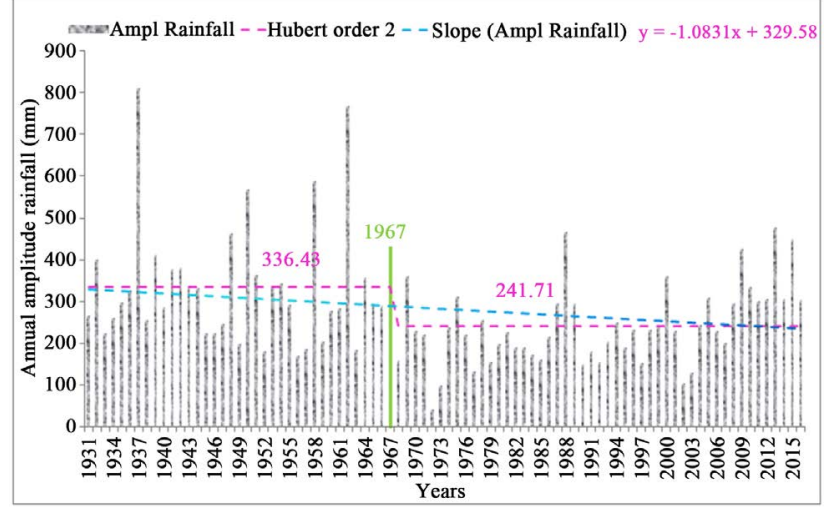

(a)

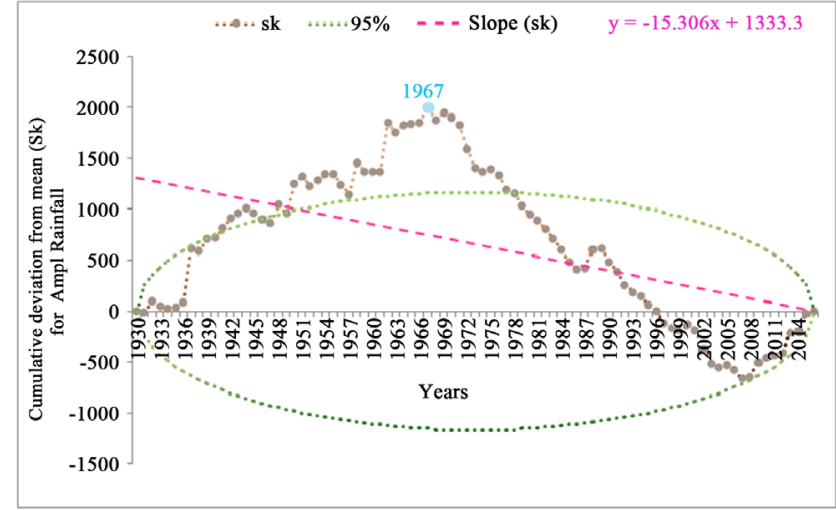

(b)

Figure 6. (a) Hubert diagram at order 2 for annual amplitude; (b) Buishand control ellipse for annual amplitude.

Table 4. Results of the Mann-Kendall test.

\begin{tabular}{ccccccc}
\hline & U (S) & $P$-value & Null Hypothesis & Trend Direction & Trend Extent & Classifying \\
\hline Tmin & +4.02 & $5.84 \times 10^{-5}$ & Rejected & Decrease & Significant & 1 \\
Tmax & -1.96 & 0.76 & Rejected & Decrease & Not Significant & 4 \\
Tmean & +1.99 & 0.06 & Rejected & Decrease & Not Significant & 3 \\
Tamp & -3.54 & $4.04 \times 10^{-4}$ & Rejected & Decrease & Significant & 2 \\
\hline
\end{tabular}




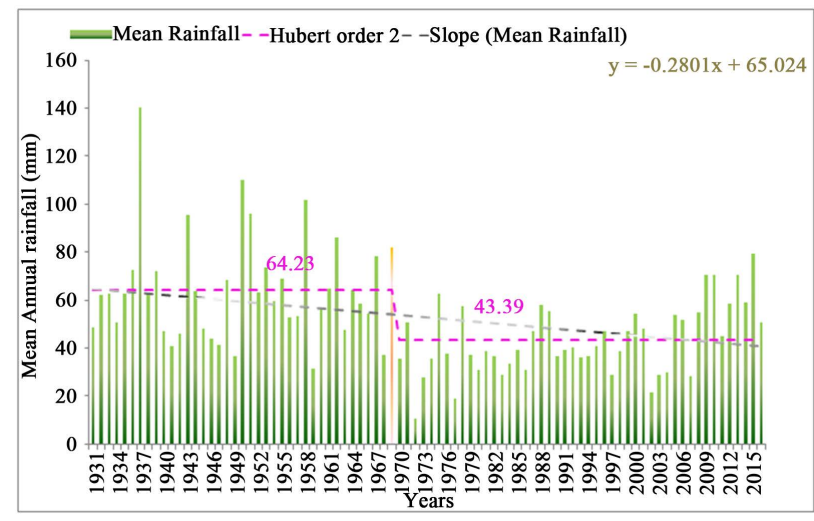

(a)

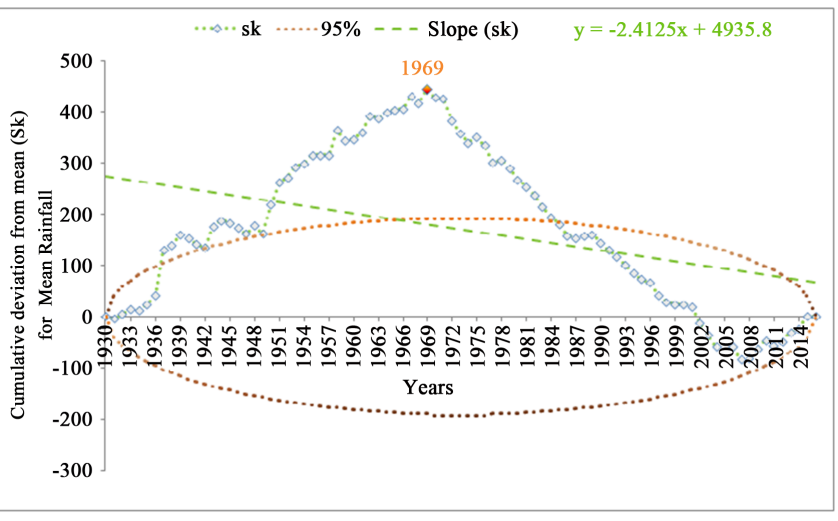

(b)

Figure 7. (a) Hubert diagram at order 2 for annual mean; (b) Buishand control ellipse for annual mean.

Table 5. Tabular results of shift test.

\begin{tabular}{cccccc}
\hline & \multicolumn{2}{c}{ Hubert Test } & \multicolumn{2}{c}{ Buishand Test } & \\
\cline { 2 - 6 } & H0 & Break Date & H0 & Break Date & Series Conclusion \\
\hline Pmin & Rejected & 1958 & Rejected & 1958 & Non-homogeneous \\
Pmax & Rejected & 1967 & Rejected & 1967 & Non-homogeneous \\
Pampl & Rejected & 1967 & Rejected & 1967 & Non-homogeneous \\
Pmoy & Rejected & 1969 & Rejected & 1969 & Non-homogeneous \\
\hline
\end{tabular}

\section{Temperature Time Series}

Results of the Buishand and Hubert rupture tests are presented in Table 6. The Figures 8(a)-11(a) and Figures 8(b)-11(b) relate respectively to the Hubert and Buishand tests of the four-temperature data considered. The table shows the two tests all reject the null hypothesis of an absence of breaks at the $5 \%$ significance level. The breaking date given by the Buishand ellipse corresponds to the date indicated by the Hubert test for each of the four temperature categories considered. This date corresponds to 1991 for the minimum temperatures (Figure 8(a) and Figure 8(b)), 1975 for the maximum temperatures (Figure 9(a) and Figure 9(b)), 1975 for the amplitudes (Figure 10(a) and Figure 10(b)) and 1993 for the mean temperatures (Figure 11(a) and Figure 11(b)). This break gives an upward trend for minimum and average temperatures and a downward trend for maximum temperatures and amplitudes. All these results lead to the conclusion that the time series is not homogeneous for each of the temperature categories considered. We can therefore, divide each series into two sub-series: from 1961-1975 and 1976-2016 for maximum temperatures; 1961-1976 and 1977-2016 for amplitudes; 1961-1991 and 1992-2016 for minimum and finally 1961-1993 and 1994-2016 for mean.

\subsection{Relating to Magnitude of Shifts}

\section{Rainfall Time Series}




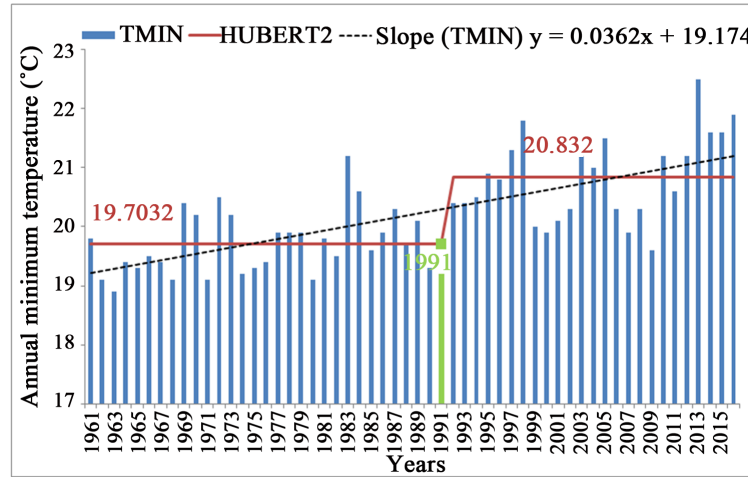

(a)

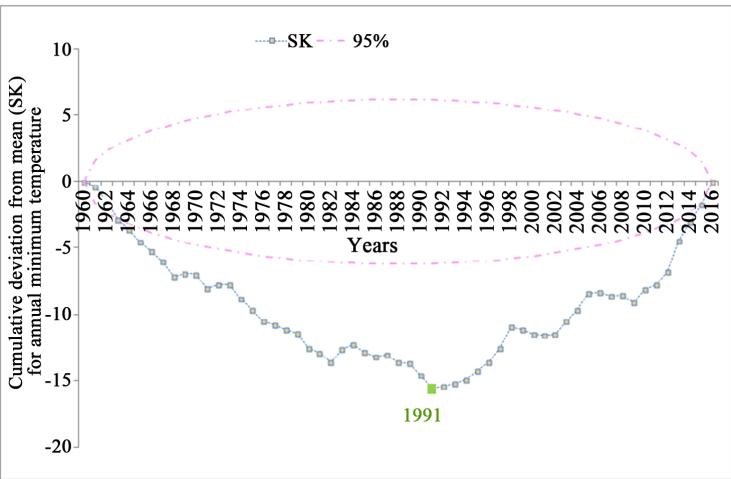

(b)

Figure 8. (a) Hubert diagram at order 2 for annual minimum; (b) Buishand control ellipse for annual minimum.

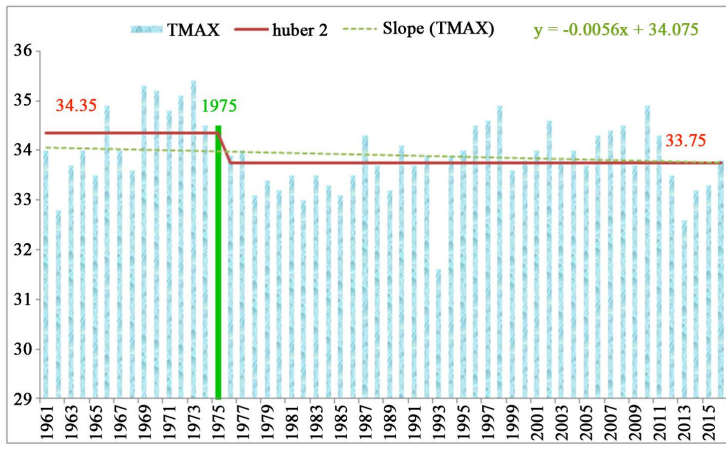

(a)

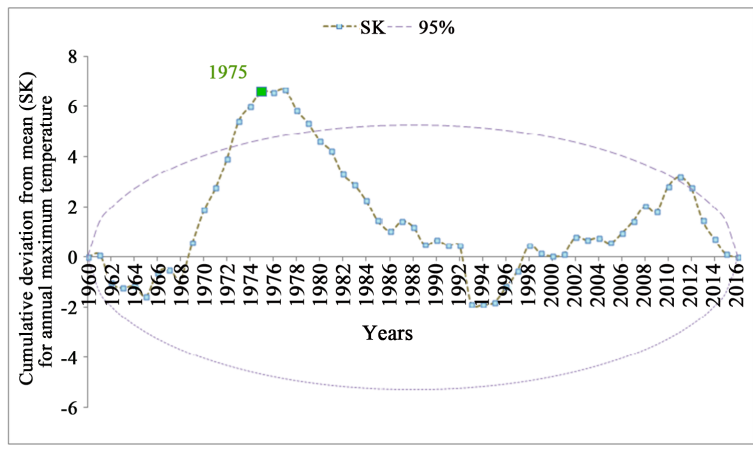

(b)

Figure 9. (a) Hubert diagram at order 2 for annual maximum; (b) Buishand control ellipse for annual maximum.

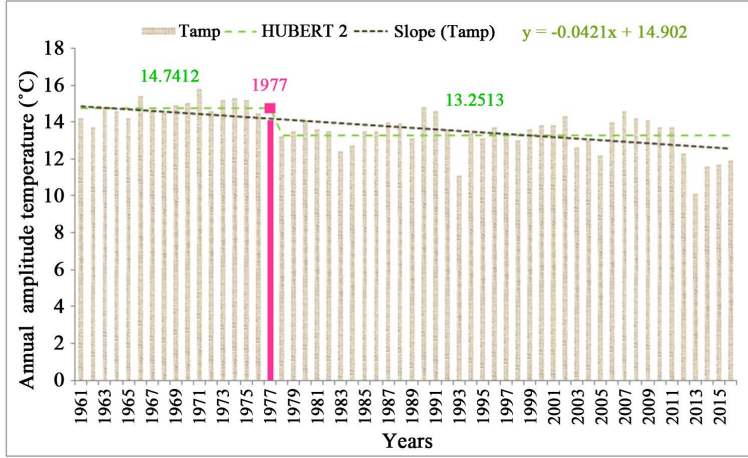

(a)

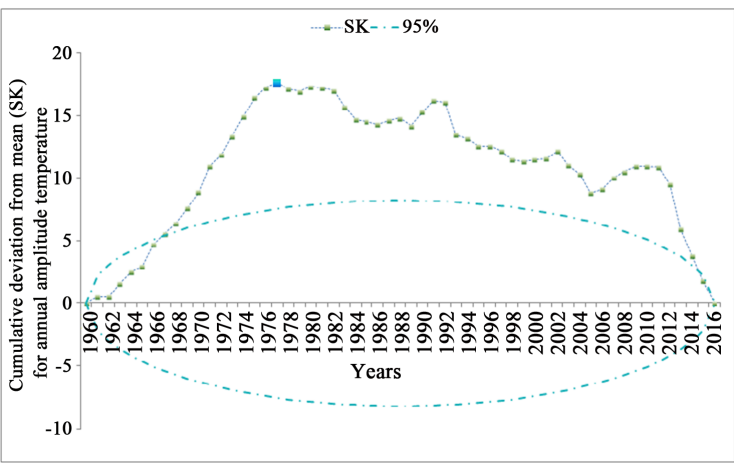

(b)

Figure 10. (a) Hubert diagram at order 2 for annual amplitude; (b) Buishand control ellipse for annual amplitude.

Table 6. Tabular results of shift test.

\begin{tabular}{cccccc}
\hline & \multicolumn{2}{c}{ Hubert Test } & \multicolumn{2}{c}{ Buishand Test } & \multirow{2}{*}{ Conclusion on Series } \\
\cline { 2 - 5 } & $\mathrm{H}_{0}$ & Break Date & H0 & Break Date & \\
\hline Tmin & Rejected & 1991 & rejected & 1991 & Non-homogeneous \\
\multirow{2}{*}{ Tmax } & Rejected & 1975 & rejected & 1975 & Non-homogeneous \\
Tampl & Rejected & 1976 & Rejected & 1976 & Non-homogeneous \\
Tmoy & Rejected & 1993 & Rejected & 1993 & Non-homogeneous \\
\hline
\end{tabular}




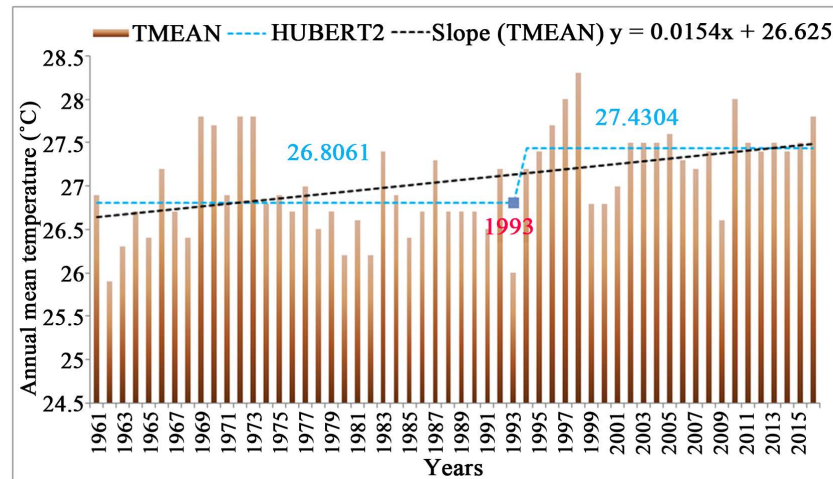

(a)

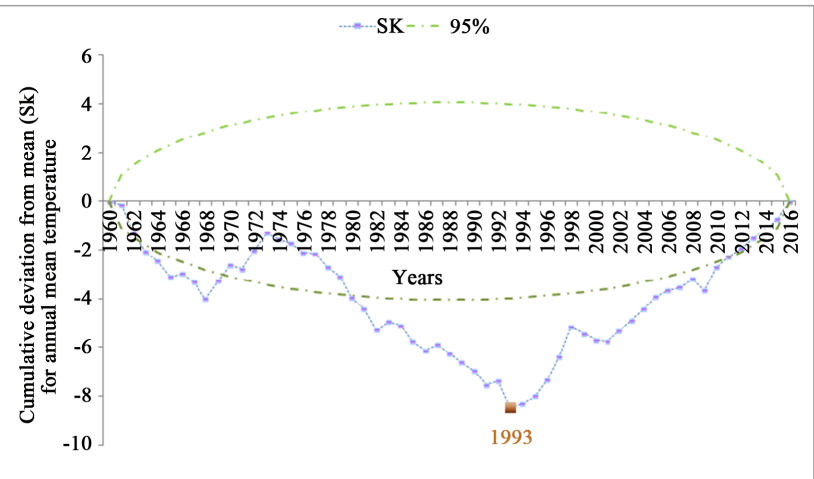

(b)

Figure 11. (a) Hubert diagram at order 2 for annual mean; (b) Buishand control ellipse for annual mean.

Table 7 shows the results of the Student test for rainfall. The analysis of the table shows that all the values of $T$ and $Z$ are above the reference value 1.96 at the threshold of $5 \%$. This translates that the rupture is significant for all the series of rains studied. In other words, the difference of the means of the two sub-series obtained on either side of the breaking point is significant for the rain.

\section{- Temperature Time Series}

Table 8 shows the results of the Student temperature test. The analysis of the table shows that all the values of $\mathrm{T}$ are greater than the reference value 1.96 at the threshold of $5 \%$. This translates that the rupture is significant for all the series of temperatures studied. In other words, the difference of the means of the two sub-series obtained on either side of the breaking point is significant for the temperature.

\subsection{Land Use/Land Cover Changes}

Eleven classes, namely: Bare soil, Beach, Settlements, Crop lands, Tidal areas, Lagoon, Mangrove, Sabkha, Somone river, Vegetated Sabkha and Forest area were distinguished and classified during the classification process. Figure 12 shows the cover and occupation changes of these classes during the periods 1954-2016. The assessment of classifying images indicates an overall accuracy, estimated at 93.15\% and a kappa coefficient equal to 0.92 . Nine classes were designed as the land cover (Mangrove, Forest area, Sabkha, Bare soil, Beach, Vegetated sabkha, Tidal area, Lagoon, and Somone River) and two classes (Settelements and Crop lands represented the land use in this study. Table 9 presents the LULC percentage changes and the change directions of each class (positive or negative).

\subsubsection{Land Cover}

The mangrove and the forest area have decreased over sixty-two-year periods from respectively $4.07 \%$ and $51.06 \%$ in 1954 to $2.65 \%$ and $10.86 \%$ in 2016 . While the barren salt area (Sabkha) has increased during the same period, from $5.29 \%$ to $18.48 \%$. The Somone River has decreased during the periods 1954-2016 from $0.38 \%$ to $0.19 \%$. The bare soil was not identified from 1954 and 1978 maps, but 


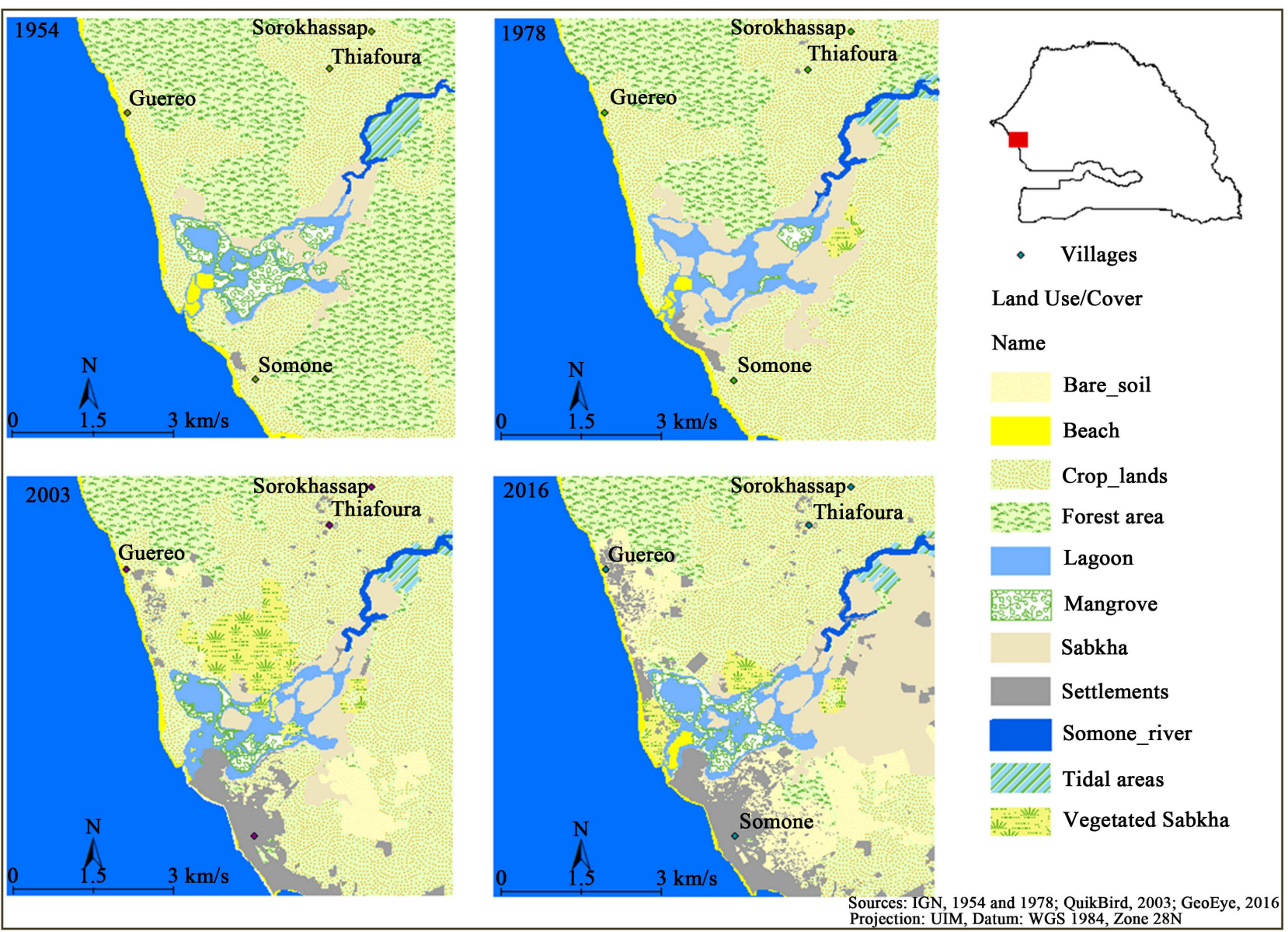

Figure 12. LULC changes over the Somone coastal lagoon from 1954 to 2016.

Table 7. Student test results.

\begin{tabular}{ccccccc}
\hline & $n_{1}$ & $n_{2}$ & $\overline{X_{1}}$ & $\overline{X_{2}}$ & $T$ & $Z$ \\
\hline Pmin & 28 & 58 & 20.06 & 8.41 & 4.262 & $\mathrm{X}$ \\
Pmax & 37 & 49 & 352.99 & 248.87 & $\mathrm{X}$ & 3.714 \\
Pmoy & 39 & 47 & 64.23 & 43.39 & $\mathrm{X}$ & 4.633 \\
Pamp & 37 & 49 & 336.43 & 241.71 & $\mathrm{X}$ & 3.346 \\
\hline
\end{tabular}

Table 8. Student test results.

\begin{tabular}{ccccccc}
\hline & $n_{1}$ & $n_{2}$ & $\overline{X_{1}}$ & $\overline{X_{2}}$ & $T$ & $Z$ \\
\hline Tmin & 31 & 25 & 20.06 & 8.41 & -4.968 & $\mathrm{X}$ \\
Tmax & 15 & 41 & 352.99 & 248.867 & +2.745 & $\mathrm{X}$ \\
Tmoy & 33 & 23 & 64.23 & 43.39 & -3.573 & $\mathrm{X}$ \\
Tamp & 16 & 40 & 336.43 & 241.71 & +5.842 & $\mathrm{X}$ \\
\hline
\end{tabular}


Table 9. Somone LULC changes classes from 1954 to 2016.

\begin{tabular}{ccccccccccccc}
\hline \multirow{2}{*}{ Name } & \multicolumn{2}{c}{1954} & \multicolumn{2}{c}{1978} & \multicolumn{2}{c}{2003} & \multicolumn{2}{c}{2016} & \multicolumn{3}{c}{ Changes \% } \\
\cline { 2 - 11 } & $\mathbf{k m}^{2}$ & $\%$ & $\mathrm{~km}^{2}$ & $\%$ & $\mathrm{~km}^{2}$ & $\%$ & $\mathrm{~km}^{2}$ & $\%$ & $1954-1978$ & $1978-2003$ & $2003-2016$ \\
\hline Bare soil & & & & & 2.24 & 3.02 & 5.91 & 10.76 & & 7.74 \\
Beach & 0.82 & 1.85 & 0.85 & 1.93 & 0.4 & 0.9 & 0.7 & 1.59 & 0.08 & -1.03 & 0.69 \\
Settlements & 0.13 & 0.29 & 0.98 & 2.23 & 3.78 & 8.38 & 4.05 & 9.21 & 1.94 & 6.16 & 0.82 \\
Crop lands & 13.95 & 31.61 & 24.17 & 54.82 & 24.75 & 54.95 & 15.47 & 35.16 & 23.22 & 0.12 & -19.78 \\
Tidal areas & 0.79 & 1.78 & 0.62 & 1.40 & 0.64 & 1.42 & 0.51 & 1.16 & -0.38 & 0.02 & -0.26 \\
Lagoon & 1.62 & 3.67 & 2.08 & 4.72 & 2.26 & 5.01 & 2.04 & 4.63 & 1.05 & 0.29 & -0.38 \\
Mangrove & 1.79 & 4.07 & 0.25 & 0.56 & 0.65 & 1.44 & 1.17 & 2.65 & -3.50 & 0.88 & 1.21 \\
Sabkha & 2.33 & 5.29 & 5.26 & 11.93 & 3.06 & 6.78 & 8.13 & 18.48 & 6.64 & -5.14 & 11.70 \\
Somone river & 0.17 & 0.38 & 0.08 & 0.17 & 0.05 & 0.12 & 0.08 & 0.19 & -0.21 & -0.05 & 0.13 \\
Vegetated Sabkha & & & 0.36 & 0.81 & 2.69 & 5.96 & 1.15 & 2.63 & & 5.15 & -3.34 \\
Forest area & 22.53 & 51.06 & 9.44 & 21.43 & 4.27 & 9.49 & 4.78 & 10.86 & -29.64 & -11.94 & 1.37 \\
\hline
\end{tabular}

they have largely increased from 2003 to 2016 at $7.74 \%$. The beach has increased for the periods 1954 and 1978 by respectively passed by $1.85 \%$ to $1.93 \%$. It has decreased from 1978 to 2003 of a percentage of -1.03 to increase again during the period $2003-2016$ of about $0.69 \%$. The tidal area was characterized by negative evolution during the periods 1954-1978 and 2003-2016. It has indeed decreased respectively of $-0.38 \%$ and $-0.26 \%$. Nevertheless, it has slightly increased from 1978 to 2003 of about $0.02 \%$. The vegetated Sabkha, which appeared in 1978 in the study area, has increased from 1978 to 2003 of 5.15\% and has decreased from 2003 to 2016 of $-3.34 \%$. Somone lagoon has permanent connections to the Atlantic Ocean, has recorded small temporal variations, observed in its areal extent. It constituted $3.67 \%\left(1.62 \mathrm{~km}^{2}\right)$ in 1954 and has then increased by $4.72 \%\left(2.08 \mathrm{~km}^{2}\right)$ in 1978 and $5.01 \%\left(2.26 \mathrm{~km}^{2}\right)$ in 2003 . A slight decrease, however, of about $4.63 \%\left(2.04 \mathrm{~km}^{2}\right)$, was recorded in 2016 . These changes might be invariably due to fluctuations in tidal sea levels. The Somone river area has undergone a considerable decline, from $0.38 \%\left(0.17 \mathrm{~km}^{2}\right)$ in 1954 to $0.19 \%\left(0.08 \mathrm{~km}^{2}\right)$ in 2016 . Although, a decrease in rainfall might play a role, but hydrologic modifications to this water body is the main cause of drying up. In 1999, six dams were built in Bandia, about $3 \mathrm{~km}$ from the mouth of the river in its upstream section to encourage floristic development and water for wildlife in the Bandia reserve. Also, in 2000, three more dams were constructed in Kissane, about $25 \mathrm{~km}$ from the mouth of the river [29].

The main impact of a climate change (fall in rainfall and an increase in temperature) is an enlargement of the salt pans (Sabkhas). Forestland decrease can be linked to the changing climate (decreasing precipitation), however a slight increase between 2003 and 2016 can be linked to the precipitation increase. Mangrove forest decreased can be linked to the Sahelian drought of the 1970s 
and 1980s. It is also important to note that logging may have also played an important role, since there were no access restrictions during this period. The raising in mangrove area between 2003 and 2016 is a result of both recent rise in rainfall amount and the establishment of the Somone lagoon as a protected area since 1999, which involving mangrove reforestation, and conservation policies [51].

\subsubsection{Land Use}

The Settlements have increased in the area during the periods 1954, 1978, 2003 and 2016 with the respective percentages of $0.29 \%, 2.23 \%, 8.38 \%$ and $9.21 \%$. While in the same periods, croplands have added from $31.60 \%\left(13.94 \mathrm{~km}^{2}\right)$ in 1954 to $54.82 \%\left(24.16 \mathrm{~km}^{2}\right)$ in 1978 and $54.94 \%\left(24.75 \mathrm{~km}^{2}\right)$ in 2003 . Nevertheless, they have decreased in 2016 , with $35.16 \%\left(15.47 \mathrm{~km}^{2}\right)$. This dynamic is obviously due to conversion of cropland areas into settlements, encouraged by tourism development. For instance, between 1994 and 2008, six straw huts were built at the lagoon border on Guereo side. Following the severe drought period, which caused soil salinization and water scarcity, there has been rural exodus from the inland to the coastal areas as rural communities' search for alternative livelihood sources, such as fishery and tourism [52]. Over the period 1954-1978, crop lands progressed while the forest area regressed. Likewise, settlements have augmented when the forest areas have more decreased 1978-2003. Finally, during the 2003-2016 period, sabkha has progressed while the crop lands have regressed.

\section{Discussion}

Somone coastal lagoon is a complex ecosystem with rich and diverse species [52]. Its position between the sea and continent favors the biodiversity development. However, it is exposed to pressures linked to the global climate change and the human activities and or development. Found on all continents, usually oriented parallel to the coast, coastal lagoons are often highly productive and highly stressed by anthropogenic inputs and human activities [53]. Sea level, temperature, precipitation, and storminess are expected to change significantly with the Global climate change and to impact coastal lagoons directly [6]. Indeed, Temperature and precipitation are strong determinants of wetland ecosystem structure and function [54] and climate change will affect the hydrology of individual wetland ecosystems mostly through changes in precipitation and temperature regimes.

Along the Senegalese littoral, there is an increase in the average sea surface temperature, due to the global climate change [55]. In fact, our climate results showed decreased trends of the precipitation in Somone's coastal lagoon within the years. While the temperature implies both decreasing and increasing trend, but the overall trend is the temperature heating. Such, Victoria wetland has experienced rising temperatures and declining rainfall since 1950, culminating in 
severe and prolonged drought since 1997 [56]. Changes in maximum and minimum temperature and in precipitation patterns may also have significant impacts on US wetlands [57].

Many coastal wetlands can adjust to predicted climate change, but human impacts, in combination with climate change, will significantly affect coastal wetland ecosystems [58]. These climatic disturbances are exacerbated by the social and urban pressures, due to anthropogenic activities and development. It is scientifically demonstrated that human being has modified interior of coastal wetlands by converting them into social and economic activities [59]. Wetland areas have decreased with human density [60]. The Somone increasing population is indicated by high densities which varied between 200 and 500 inhabitants $/ \mathrm{km}^{2}$ in this area [61]. This is partially due to the rural exodus, which has followed the agricultural crisis in rural areas (reduced rainfall, land degradation) and which caused the rush of people toward the coast, to explore other activities such as fishery and aquaculture. The consequences are the pressures on fish and oyster resources (ocean and inland fisheries) in addition to shellfish harvesting in lagoons and estuaries, which implied the resource scarcity. Additionally, between 1946 and 1978, 85\% of the Somone area was progressively replaced by unvegetated mudflats in the intertidal zones and by barren area in the supratidal zones. Until 1990, this was mainly a result of traditional wood harvesting [29]. Comparatively, In Delta State, Nigeria, high rates of deforestation in mangroves were linked mainly to agriculture and aquaculture activities [62]. Otherwise, the population increase has led to an unprepared occupation of sensitive areas the shoreline, in the lagoons borders [63], exacerbated by the emergence of activities such as tourism. According to [29], increasing seaside tourism was accompanied by the real estate and construction pressures and unregulated development of the Somone coastline. In the Ceuta coastal lagoon system, Sinaloa, Mexico, the development of shrimp aquaculture is causing a new pressure on this environment, and it has changed the coastal landscape covering 3190 ha in less than 15 years, mainly replacing bare soil and salt marsh [64].

Finally, this paper results showed the forest area decreasing in favor to the settlements. The croplands diminishing between 2003 and 2016 can be linked to developments of tourism activities which needed new areas for settlements building (hostels, residences, straw huts). Consequently, the extension of the habitats in sensitive areas is one of the main causes of deterioration of coastal ecosystems in the Petite Côte of Senegal [65] [66]. Such, high rates of deforestation within a country are most commonly linked to population growth and poverty, shifting cultivation in large tracts of forests [67]. Even, in the Ebrié lagoon, Côte d'Ivoire, the human pressures are mainly the development of traditional fisheries, aquaculture and construction of dams and other planned, to response to the urban development in Abidjan. This has led huge impacts on Ebrié lagoons. Anthropogenic influences have then highly destroyed the lagoon ecosystems, nevertheless, agriculture, cattle, forestry, and urbanization have been the main transfor- 
mers of the natural land cover, but the coastal systems, particularly wetlands, are degraded in other ways, e.g. dyking and filling, nutrient enrichment, addition of toxins, extensive invasion by non-native species, and the decrease in average area and loss of connectivity between wetlands and other ecosystems [64]. As can be seen from the results of [68], changes in the Segara Anakan lagoon, Java, Indonesia area are almost exclusively caused by high sedimentation rates, which has been one of the main management concerns in the river basin, particularly regarding the impacts on the low land activities.

Thus, pressures on coastal lagoons are diverse and multiple of different ways. According to [69], Coastal systems are in one sense, particularly sensitive to three key drivers related to climate change: sea level, ocean temperature, and ocean. In another sense, the population and assets exposed to coastal risks as well as human pressures on coastal ecosystems will increase significantly in the coming decades due to population growth, economic development, and urbanization.

Understanding, the climate parameter variability and its inks to the LULC changes in Somone coastal lagoon within the Watershed, is the critical points to understand the dynamic of this ecosystem and plane sustainable conservation and adaptation policies. In this sense, further studies are planned, to examine chemical properties of water and the chlorophyll A (phytoplankton community).

\section{Conclusion}

This study made a comparison between the vagaries of the climate and LULC change within the years in the Somone coastal ecosystem. It is obvious that this information constitutes basic elements of a reflection in coping policies with the global warming, by the developing adequate adaptation strategies for resilience of the ecosystem and species such as coastal lagoons. Results showed a downward trend of the different rainfall data considered. These trends are much clearer for minimal and average rainfall than for maximum rainfall and annual amplitudes. As far as the temperatures are concerned, the results showed an upward trend for the minimum and average temperatures and a downward trend for the maximum temperature amplitudes. The upward trend is much more pronounced for the minimum temperatures than for the average temperatures. The downward trend is much more marked for the amplitudes than for the maximum temperatures. Mann-Kendall test showed a downward trend at the 5\% threshold for all four categories of rainfall used. Except for the amplitudes, this trend is significant for the minimum, average and maximum rains. For temperature data, the test indicates a downward trend for maximum temperatures and amplitudes and an upward trend of minimum and mean temperatures at the 5\% level of significance. This trend is not statistically significant for maximum and average temperatures, whereas for maximum temperatures and amplitudes it is. From breaks, the tests of Hubert and Buishand indicate a downward rupture at the level of significance of $5 \%$ for four rainfall data considered and give the same date of rupture of 1958. For the temperatures, these two tests indicate an upward dis- 
ruption for minimum and average temperatures and a downward trend for maximum temperatures and amplitudes. These tests give 1975, 1976, 1991 and 1993 as the break date for maximum temperatures, amplitudes, minimum temperatures and mean temperatures. This study of evolution of climate through rainfall and temperature analysis, undeniably presents several interests in ecosystem and species functioning understanding and management for building sustainable coping strategies for climate change. Changes in the LULC are closely linked to these climatic changes and other human pressures: decrease of the mangrove from 1954 to 2016, corresponding to the fall at the rainfall: decreasing of forest area in favor of settlements and croplands. The croplands decreasing in favor of urban settlements, is one indicator of agriculture land crisis, because of rainfall decreasing and the tourism development. To confirm these break-up dates and the trends estimated values, it would be interesting to apply the approach presented here to all stations in the Senegalese littoral, to be able to understand ecosystem and species functioning and behaviors such as coastal lagoons and water-bird's species facing with climate change. As far as the weather (leading by temperature, and rainfall parameters) is of major importance for the population dynamics of bird [70]. Indeed, water is the key parameter of wetlands function and is the biochemical basis of all organisms and precipitations are the main source of this water [71].

\section{Acknowledgements}

This study was undertaken under the framework of WASCAL (West African Science Service Center on Climate Change and Adapted Land Use), a BMBF Germany sponsored program. Authors also wish to acknowledge the direction of ANACIM (National Agency of Civil Aviation and Meteorology of Senegal) and the National Cartography Direction of Senegal, for putting reliable and complete data at our disposal within this study.

\section{References}

[1] UNESCO-WWAP (United Nations Educational Scientific and Cultural Organization World Water Assessment Programme) (2006) Water: A Shared Responsibility: The United Nations World Water Development Report 2. http://www.unesco.org/water/wwap/wwdr/wwdr2/

[2] Xu, Z.X., Chen, Y.N. and Li, J.Y. (2004) Impact of Climate Change on Water Resources in the Tarim River Basin. Water Resources Management, 18, 439-458. https://doi.org/10.1023/B:WARM.0000049142.95583.98

[3] Erwin, K.L. (2009) Wetlands and Global Climate Change: The Role of Wetland Restoration in a Changing World. Wetlands Ecology and Management, 17, 71-84. https://doi.org/10.1007/s11273-008-9119-1

[4] Torresan, S., Critto, Æ.A., Dalla, Æ.M., Harvey, N. and Marcomini, Æ.A. (2008) Assessing Coastal Vulnerability to Climate Change: Comparing Segmentation at Global and Regional Scales. Wetlands Ecology and Sustainability Science, 3, 45-65. https://doi.org/10.1007/s11625-008-0045-1 
[5] Kashaigili, J.J., Levira, P., Liwenga, E. and Mdemu, M.V. (2014) Analysis of Climate Variability, Perceptions and Coping Strategies of Tanzanian Coastal Forest Dependent Communities. American Journal of Climate Change, 3, 212-222. https://doi.org/10.4236/ajcc.2014.32020

[6] Anthony, A., Atwood, J., August, P., Byron, C., Cobb, S., Foster, C., Fry, C., Gold, A., Hagos, K., Heffner, L., Kellogg, D.Q., Lellis-Dibble, K., Opaluch, J., Oviatt, C., Pfeiffer-Herbert, A., Rohr, N., Smith, L., Smythe, T., Swift, J. and Vinhateiro, N. (2009) Coastal Lagoons and Climate Change: Ecological and Social Ramifications in U.S. Atlantic and Gulf Coast Ecosystems. Ecology and Society, 14, 8.

http://www.ecologyandsociety.org/vol14/iss1/art8/

https://doi.org/10.5751/ES-02719-140108

[7] Traore, V.B., Soussou, S., Cisse, M.T., Seni, T., Sidy, F., Diaw, A.T., Hyacinthe, S. and Malanda, E.N. (2014) Trends and Shifts in Time Series of Rainfall and Runoff in the Gambia River Watershed. International Journal of Environmental Protection and Policy, 2, 138-146. https://doi.org/10.11648/j.ijepp.20140204.13

[8] Lobell, D.B., Burke, M.B., Tebaldi, C., Mastrandrea, M.D., Falcon, W.P. and Naylor, R.L. (2008) Prioritizing Climate Change Adaptation Needs for Food Security in 2030. Science, 319, 607-610. https://doi.org/10.1126/science.1152339

[9] Goulden, M., Conway, D. and Persechino, A. (2009) Adaptation to Climate Change in Transboundary River Basins in Africa. Hydrological Sciences Journal, 54, 805828. https://doi.org/10.1623/hysj.54.5.805

[10] Piyoosh, R. and Bhavna, K. (2015) Impact of Climate Change on Life and Livelihood of Indigenous People of Higher Himalaya in Uttarakhand, India. American Journal of Environmental Protection, 3, 112-124.

[11] Sarr, B. (2012) Present and Future Climate Change in the Semi-Arid Region of West Africa: A Crucial Input for Practical Adaptation in Agriculture. Atmospheric Science Letters, 13, 108-112. https://doi.org/10.1002/asl.368

[12] Emiola, G., Sarr, A., Sylla, M.B., Diallo, I., Chris L., Dosio, A., Dhiediou, A., Kamga, A., Klutse, N.A.B., Brue, H., Grigory, N. and Benjamin, L. (2013) Climatology, Annual Cycle and Interannual Variability of Precipitation and Temperature in CORDEX Simulations over West Africa. International Journal of Climatology, 17.

[13] ECOWAS-SWAC/OECD/CILSS (2008) Climate and Climate Change. The Atlas on Regional Integration in West Africa. Environment Series. http://www.atlas-westafrica.org

[14] Biazen, M. (2014) Effect of Climate Change and Variability on the Livelihoods of Local Communities: In the Case of Central Rift Valley Region of Ethiopia. Open Access Library Journal, 1, 453. https://doi.org/10.4236/oalib.1100453

[15] Paturel, J.E., Boubacar, I. and L'aour A. (2004) Annual Rainfall Analysis in West and Central Africa during the 20th Century. Sud Sciences et Technologies, 13, 40-46.

[16] Thomas, C.D., Cameron, A., Green, R.E., Bakkenes, M., Beaumont, L.J., Collingham, Y.C. and Erasmus, B.F.N. (2003) Extinction Risk from Climate Change. Nature, 427, 145-148. https://doi.org/10.1038/nature02121

[17] Lloret, J., Marín, A. and Marín-Guirao, L. (2008) Is Coastal Lagoon Eutrophication Likely to Be Aggravated by Global Climate Change? Estuarine, Coastal and Shelf Science, 78, 403-412.

[18] Urama, K.C. and Ozor, N. (2010) Impacts of Climate Change on Water Resources in Africa : The Role of Adaptation. In: Climate Adaption, 1-29. https://pdfs.semanticscholar.org/2eac/cdb9c3b59556f2b39bd549482a773010fc8f.pdf 
[19] Ndiaye, M.L., Toure, M.A., Malomar, G., Diaw, A.T. and Beye, A.C. (2016) Contribution of Remote Sensing to the Study of Spatiotemporal Evolution of Rainfall in Senegal: Exploitation of TRMM 3B43 Low Spatial Resolution. Journal of Multidisciplinary Engineering Science Studies, 2, 748-752.

[20] Ouarda, T.B.M.J., Rasmussen, P.F., Cantin, J.F., Bobée, B., Laurence, R., Hoang, V.D. and Barabé, G. (1999) Identification of a Hydrometric Network for Monitoring Climate Change in the Province of Quebec. Journal of Science of Water, 12, 425-448.

[21] Edjrogan, M.T., Ndiaye, M.L., Traore V.B., Sambou, H., Nelly, C.K., Sy, B.A. and Diaw, A.T. (2017) Characterization and Analysis of Rainfall Variability in the Mono-Couffo River Watershed Complex, Benin (West Africa). Resources and Environment, 7, 13-29.

[22] Singh, R.S., Narain, P. and Sharma, K.D. (2001) Climate Changes in Luni River Basin of Arid Western Rajasthan (India). Vayu Mandal, 31, 103-106.

[23] Schubert, S., Dole, R., van den Dool, H., Suarez, M. and Waliser, D. (2002) Prospects for Improving Forecasts of Weather and Short-Term Climate Variability on Subseasonal (2-Week to 2-Month) Time Scales. NASA Technical Report Series on Global Modeling and Data Assimilation, NASA/TM-2002-104606, 23, 171.

[24] Tali, P.A. and Kanth, T.A. (2016) Temperature Variability Analysis of Gulmarg and Srinagar, Kashmir Valley, J\&K, India. Journal of Geography, Environment and Earth Science International, 4, 1-11. https://doi.org/10.9734/JGEESI/2016/21344

[25] Otterman, J. (1974) Baring High Albedo Soil by Overgrazing: A Hypothesized Desertification Mechanism. Sciences, 186, 531-533.

[26] Nicholson, S.E., Tucker, C.J. and Ba, M.B. (1998) Desertification, Drought, and Surface Vegetation: An Example from the West African Sahel. American Meteorological Society, 818-829. https://doi.org/10.1175/1520-0477(1998)079<0815:DDASVA >2.0.CO;2

[27] Charney, J.G. (1975) Dynamics of Deserts and Drought in the Sahel. Quarterly Journal of the Royal Meteorological Society, 101, 193-202.

[28] Benga, E. (1984) Geomorphological Study of the Mangrove of the Somone Estuary. Report Study of Mangroves and Estuaries of Senegal Saloum and Somone, UNESCO-EPEEC, 55-70.

[29] Sakho, I., Mesnage, V., Deloffre, J., Lafite, R., Niang, I. and Faye, G. (2011) The Influence of Natural and Anthropogenic Factors on Mangrove Dynamics over 60 Years: The Somone Estuary, Senegal. Estuarine, Coastal and Shelf Science, 94, 93101.

[30] Doumouya, F.R., Traore, V.B., Sadio, M., Sambou, H., Issaka-Ali, A.H., Diaw, A.T., Sambou, B. and Beye, A.C. (2016) Rainfall Variability in Sine Saloum River Basin in a Context of Climate Change and Variability. Advances in Research, 6, 1-12. https://doi.org/10.9734/AIR/2016/25349

[31] Lawin, A.E., Afouda, A. and Lebel, T. (2011) Analyse de la variabilité du régime pluviométrique dans la région agricole d'Ina au Benin. European Journal of Scientific Research, 50, 425-439.

[32] Dietz, E.J. and Killeen, T.J.A. (1981) Nonparametric Multivariate Test for Monotone Trend with Pharmaceutical Applications. Journal of the American Statistical Association, 76, 169-174.

[33] Hirsch, R.M. and Slack, J.R. (1984) A Nonparametric Trend Test for Seasonal Data with Serial Dependence. Water Resources Research, 20, 727-732. 
https://doi.org/10.1029/WR020i006p00727

[34] Thierry, F. (2009) L'évolution des températures à Nantes entre 1946 et 2000 Analyses statistiques des ruptures de tendance et interprétations. Cahiers nantais, 2, 15-21.

[35] Tabari, H. and Talaee, P.H. (2011) Temporal Variability of Precipitation over Iran: 1966-2005. Journal of Hydrology, 396, 313-320.

[36] Mann, H.B. (1945) Mann-Kendall. Non-Parametric Test against Trend. The Econometric Society, 13, 245-259. http://www.jstor.org/stable/1907187

[37] Traore, V.B., Ndiaye, M.L., Mbow, C., Malomar, G., Sarr, J., Beye, A.C. and Diaw, A.T. (2017) Khronostat Model as Statistical Analysis Tools in Low Casamance River Basin, Senegal. World Environment, 1, 10-22.

[38] Caussinus, H. and Mestre, O. (2004) Detection and Correction of Artificial Shifts in Climate Series. Applied Statistics, 3, 405-425.

https://doi.org/10.1111/j.1467-9876.2004.05155.x

[39] Boyer, J.F. (2002) Khronostat Software for Statistical Analysis of Time Series. IRD UR2, Program 21 FRIEND AOC, UMRGBE Hydrology Team, University of Montpellier II, Paris Mines School.

[40] Hubert, P. (2000) Segmentation Procedure as a Tool for Discrete Modeling of Hydro Meteorological Regimes. Stochastic Environmental Research and Risk Assessment, 14, 297-304. https://doi.org/10.1007/PL00013450

[41] Hubert, P., Bader, J.C. and Bendjoudi, H.A. (2007) Century of Annual Flows of the Senegal River. Hydrological Sciences Journal, 52, 68-73. https://doi.org/10.1623/hysj.52.1.68

[42] Rosine, M.N.F., Nagnin, S., Traore, V.B., Théophile, L., Soussou, S. and Tanina, S. (2014) Climate Variability and Its Impact on Surface Water Resources: The Case of Stations of Bocanda and Dimbokro, East-Central of Ivory Coast in West Africa. Africa Science, 10, 118-134.

[43] Buishand, T.A. (1982) Some Methods for Testing the Homogeneity of Rainfall Records. Journal of Hydrology, 58, 11-27.

[44] Buishand, T.A. (1984) Tests for Detecting a Shift in the Mean of Hydrological Time Series. Journal of Hydrology, 73, 51-69.

[45] Maftei, C., Alina, B., Constantin, B. and Cristina, S. (2007) Change Points Detection and Variability Analysis of some Precipitation Series. Recent Researches in Computational Techniques. Non-Linear Systems and Control, 232-237.

[46] Zabell, S.L. (2008) On Student's 1908 Paper the Probable Error of the Mean. Journal of the American Statistical Association, 103, 1-7. https://doi.org/10.1198/016214508000000030

[47] Nob, P., Shivaprasad, A., Karikalan, R., Dilipan, E., Thangaradjou, T. and Sivakuma, K. (2010) Microlevel Mapping of Coastal Geomorphology and Coastal Resources of Rameswaram Island, India: A Remote Sensing and GIS Perspective. Journal of Coastal Research, 263, 424-428. https://doi.org/10.2112/08-1119.1

[48] Mas, J.F, Puig, H. and Palacio, J.L. (2004) Modelling Deforestation Using GIS and Artificial Neural Networks. Environmental Modelling and Software, 19, 4611-4471.

[49] Dwiwedi, R.S., Kumar, A.B. and Tewari, K.N. (1997) The Utility of Multi-Sensor Data for Mapping Eroded Land. International Journal of Remote Sensing, 18, 2303 2318. https://doi.org/10.1080/014311697217620

[50] Richards, G.T., Lacy, M., Storrie-Lombardi, L.J., Hall, P.B., Gallagher, S.C., Hines, 
D.C., Fan, X., Papovich, C., Vanden Ber, D.E., Trammell, G.B., Schneider, D.P, Vestergaard, M., York, D.G., Jester, S., Anderson, S.F., Budavari, T. and Szalay, A.S. (2006) Spectral Energy Distributions and Multiwavelength Selection of Type $1 \mathrm{Qu}-$ asars. The Astrophysical Journal Supplement Series, 470-497. https://doi.org/10.1086/506525

[51] DPN (2010) Plan de gestion de la Reserve naturelle d'Intérêt communautaire de la Somone.

[52] Barry, N.Y. (2012) Changement climatique, évolution de la mangrove et services écosystémiques dans l'estuaire de la Somone. Mémoire de Master 2. Université cheikh Anta DIOP de Dakar/Master/Chaire UNESCO sur la Gestion Intégrée et Développement Durable du Littoral Ouest africain, 82.

[53] Kjerfve, B. (1994) Coastal Lagoons. Elsevier Oceanography Series, Vol. 60, 8.

[54] Mulholland, P.J., Ronnie, B.G.., Coutant, C.C., Hornberger, G., Meyer, J.L., Robinson, P.J., Stenberg, J.R., Turner, R.E., Francisco, V.H. and Wetzel, R.G. (1997) Effects of Climate Change on Freshwater Ecosystems of the South-Eastern United States and the Gulf Coast of Mexico. Hydrological Processes, 11, 949-970. https://doi.org/10.1002/(SICI)1099-1085(19970630)11:8<949::AID-HYP513>3.0.CO $\underline{; 2-\mathrm{G}}$

[55] Ba, K., Thiaw, M., Lazar, N., Sarr, A., Brochier, T., Ndiaye, I., Faye, A., Sadio, O., Panfili, J., Thiaw, O.T. and Brehmer, P. (2016) Resilience of Key Biological Parameters of the Senegalese Flat Sardinella to Overfishing and Climate Change. PLoS ONE, 11, e0156143. https://doi.org/10.1371/journal.pone.0156143

[56] Jin, C., Cant, B. and Todd, C. (2009) Climate Change Impacts on Wetlands in Victoria and Implications for Research and Policy. Rthur Rylah Institute for Environmental Research Technical Series No. 1994, 49.

[57] Burkett, V. and Kusler, J. (2000) Climate Change: Potential Impacts and Interactions in Wetlands of the United States. Journal of the American Water Resources Association, 36, 8. https://doi.org/10.1111/j.1752-1688.2000.tb04270.x

[58] Day, J.W., Christian, R.R., Boesch, D.M., Yáñez-Arancibia, A., Morris, J., Twilley, R.R., Naylor, L., Schaffner, L. and Stevenson, C. (2008) Consequences of Climate Change on the Ecogeomorphology of Coastal Wetlands. Estuaries and Coasts, 31, 477-491. https://doi.org/10.1007/s12237-008-9047-6

[59] Michener, W.K., Blood, E.R., Bildstein, K.L., Brinson, M.L. and Gardner, L.R. (1997) Climate Change, Hurricanes and Tropical Storms, and the Rising Sea Level in Coastal Wetlands. The Ecological Society of America, 770-801. https://doi.org/10.1890/1051-0761(1997)007[0770:CCHATS]2.0.CO;2

[60] Gibbs, J.P. (2000) Wetlands Loss and Biodiversity Conservation. Conservation Biology, 14, 314-317. https://doi.org/10.1046/j.1523-1739.2000.98608.x

[61] Agence Nationale de la Statistique et de la Démographie (2013) Recensement Général de la Population et de l'Habitat, de l'Agriculture et de l'Elevage. République du Sénégal Ministère de l'Economie, des Finances et du Plan, 418 p.

[62] Omo, O., Omo, I., Olobaniyi, S.B., Akunna, J., Venus, V., Maina, J.M. and Paradzayi, C. (2011) Mangrove Vulnerability Modelling in Parts of Western Niger Delta, Nigeria Using Satellite Images, GIS Techniques and Spatial Multi-Criteria Analysis (SMCA). Environmental Monitoring and Assessment, 39-51.

[63] Faye, I.M.N.B. (2010) Dynamique du trait de côte sur les littoraux sableux de la Mauritanie à la Guinée Bissau (Afrique de l'Ouest): Approche régionale et locale par photo-interprétation, traitement d'images et analyse de cartes anciennes. thèse de 
doctorat, université de Bretagne Occidentale, $321 \mathrm{p}$.

[64] Perez, F.A., Luna, A.R., Turner, J., Berlanga-Robles, C.A. and Jacob, M.G. (2003) Land Cover Changes and Impact of Shrimp Aquaculture on the Landscape in the Ceuta Coastal Lagoon System, Sinaloa. Mexico Ocean \& Coastal Management, 46, 583-600

[65] Dieye, E.H.B., Diaw, T.A., Sané, T. and Ndour, N. (2010) Dynamics of the Saloum Estuary Mangrove (Senegal) from 1972 to 2010. Environment, Nature, Paysage. European Review of Geography, 18.

[66] Ndong, J.-B. (1995) The Evolution of Rainfall in Senegal and the Consequences of the Recent Drought on the Environment. Revue de géographie de Lyon, 70, 193-198. https://doi.org/10.3406/geoca.1995.4212

[67] Mather, A.S. and Needle, C.L. (2000) The Relationships of Population and Forest Trends. The Geographical Journal, 166, 2-13. https://doi.org/10.1111/j.1475-4959.2000.tb00002.x

[68] Ardli, E.R. and Wolff, M. (2008) Quantifying Habitat and Resource Use Changes in the Segara Anakan Lagoon (Cilacap, Indonesia) over the Past 25 Years (1978-2004). Asian Journal of Water, Environment and Pollution, 5, 59-67.

[69] Wong, L.A., Chen, J.C., Xue, H., Dong, L.X., Su, J.L. and Heinke, G. (2003) A Model Study of the Circulation in the Pearl River Estuary (PRE) and Its Adjacent Coastal Waters. Journal of Geophysical Research, 108, 17.

[70] Stenseth, N.C., Mysterud, A., Ottersen, G., Hurrel, J., Chan, K.-S. and Lima, M. (2002) Ecological Effects of Climate Fluctuations. Science, 297, 1292-1296. https://doi.org/10.1126/science.1071281

[71] Ndiaye, A., Awais, A. and Diop, M.D. (2003) Module de formation sur la gestion des zones humides et le suivi des oiseaux d'eau. Wetlands International, 69.

\section{Submit or recommend next manuscript to SCIRP and we will provide best service for you:}

Accepting pre-submission inquiries through Email, Facebook, LinkedIn, Twitter, etc. A wide selection of journals (inclusive of 9 subjects, more than 200 journals) Providing 24-hour high-quality service User-friendly online submission system Fair and swift peer-review system Efficient typesetting and proofreading procedure Display of the result of downloads and visits, as well as the number of cited articles Maximum dissemination of your research work

Submit your manuscript at: http://papersubmission.scirp.org/

Or contact ajcc@scirp.org 